\title{
インド古典修辞学における詩的欠陥（doșa）について —ダンディン著『美文体の鏡』を中心に-
}

\section{和 田悠 元}

インド古典修辞学における doṣa（詩的欠陥）に関する考究は gunaへのそれと同 様に，当時の詩論家たちにとって重要なトピックであった. doṣaに関する記述は Bharata の Nātyaśāstraに既に見られ，爾後一千有余年，多くの詩論家たちによっ て定義・分類されてきた。

Bharata に続くDandin（=D, 8c.）もその例に漏れず，その主著 $K \bar{A}$ 第 3 章の 60 詩節を割いて, 10 種の doṣa を解説している.

doṣa とは「文学, 特に美文体詩（kāvya）に扔いてその詩自体を台無しにしてし まう要素」であり，詩人にとって看過すべからざる概念である．自らも作家であ る D も, その重要性について alamkāra guṇaの解説に先立って,「端正なる (sundara) 肢体（vapus）も一つの白攋（śvitra）の斑点によって醜悪になる」という 譬喻を用いて言及している $(K \bar{A} 1.7)$. 即ちこれは「詩人は詩作にあたって修辞技 巧を弄して精緻な美文体を構筑する前提として，まず污点（=欠陥）を詩中から 排除すること」に腐心すべきであることを示唆しており， doṣa の排除は美文体 詩作における基礎条件と言えるであろう。本稿はこうした doṣa を巡るユニーク な議論について $K \bar{A} の$ 記述に即して概括することを目的としている.

(1) apārtha（無意味）

apārtha とは全体としての意味が欠如していることである．但し惑乱者（unmatta）・ 酩酊者（matta）・幼童（bāla）の場合は適用されない $(K \bar{A} 3.128)$ ．KA 3.129 の詩例 に見られるように，相互に脈絡のない 4 つの文が並記されている場合，apārtha という doṣaに陥っていると見なされる。

(2) vyartha（無意義）

vyartha とは文（vākya）あるいは作品（prabandha）における文脈の不一致から生 じる欠陥であると定義される（KĀ3.131）。但し，不安定な心をもつ者（asvastha-citta） の言説としては是認される. KA 3.132 は D が示した vyartha の詩例であるが, そ れは 3 つ文から構成されており, 最初と中間の文は矛盾をきたしてはいないが, 
最初と最後の文は敵の存在に関して，相互に矛盾している.

(3) ekārtha（同義語反復）

ekārtha とは同義語の反復即ち tautologyである（KĀ 3.135）。但し憐憫（anukampā） 等の感情の表現においては修辞上の飾り (alamkriyā) となると規定される (KA 3.137$)$.

KĀ 3.136 は雲を意味する “taditvat”，“stanayitnu”，“ambhodhara”が執拗に使用 されているため, doṣaを含む詩となっている.

(4) sasamśaya（疑惑を伴うもの）

sasamśaya は意味を決定するために（nirnaya-artham）使用された（prayukta）言葉 （vacas）が疑い（samśaya）を生じさせてしまうという doṣaである(KĀ 3.139)。但 し疑いを生じさせるために使用される場合は，言葉の飾り（alamkriyā）となる（KA 3.141).KĀ 3.140 は “ārāt”という副詞が「遠く」「近く」という両義を有するた めに，その語が意味を決定するために使用されているにもかかわらず，疑いを生 じさせてしまうため, doṣaを含む詩となる。

(5) apakrama (不正順序)

apakrama は統語論的欠陥である. 即ち先行する叙述の順序を後続する叙述が 守らないことである（KA 3.144）。KA 3.145において，「世界の(1)維持 (sthiti)・(2) 創造（nirmāna）・(3)破壊（samhāra）の原因である」という形容詞と，それにかかる $\lceil(3)$ Śambhu (=Śiva) ・ (1) Nārāyaṇa $(=$ Viṣnu $) \cdot(2)$ ambhoja を胎とする者（=Brahmā $) 」$ という複合語において，各々の神々と彼らの司るべき職能の順序が一致していな いため，この詩は doṣa を含んでいると考えられる。但し順序の認識の了知の原 因としての努力（yatna）が為されるならば，doṣaとはならない（KĀ 3.146）。

(6) sabda-hīna（正しい言葉の欠如）

正しい言葉の欠如とは，文法的な欠陷である。詩例（KĀ 3.149）において見ら れる avate と bhavate, mahārājan は本来それぞれ avati, bhavatah, mahārāja でなけ ればならないため文法的な doṣaを含む詩節と見なされるのである. 但し文法学 の細かな規定に鈍い詩人の作中に現れる場合，ある程度容認される（KA 3.148 , 151).

\section{(7) yati-bhrașța（中間休止を欠くもの）}

中間休止（yati）とは，韻文（śloka）における韻律学（chandas）の教典に規定さ れた句切り (caesura) のことであり，それを欠くものはdoșaとなる. 但しそれが 耳に不快でない場合は容認される。Dは Mandākrāntā 韻律（17×4）による詩例を 示すが,この韻律は各詩脚の 4 及び 10 音節目の直後に中間休止が存在しなけれ 
ばならないが，それを欠いている（KĀ 3.153）。

(8) bhinna-vṛtta（不適当な䫓律を有するもの）

韻文において，諸音節の不足と過剰，あるいは長短が慣例通りでないものは bhinna-vṛtta と呼ばれる（KĀ 3.156）。D は Anuṣtubh 韻律 $(8 \times 4)$ と Upendravajrā 韻 律 $(11 \times 4)$ の 2 つの詩によって，前者においては音節の不足と過剰を（KĀ 3.157）, 後者においては第 1 詩脚に不適切な長音, 第 3 詩脚に不適切な短音が配置されて

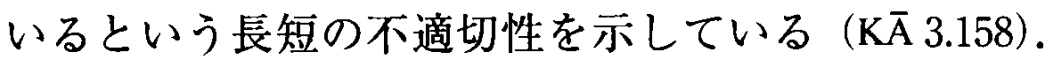

(9) visamdhika（誤連声)

visamdhika とは本来連声すべき箇所で連声がなされていないという doșaであ

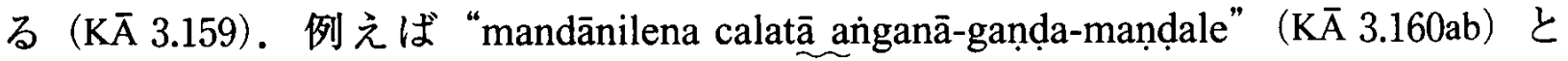
いう文章は波線の箇所が連声して̄にななねばならないため, 誤連声という doṣa を含む詩節と考えられる，他方，“māna^īrṣye iha śīryete strīṇām himaṛtau priye” (KA 3.161）の破線の箇所は一見連声して a になるべきもののように見えるが, Pān 1.1.11 の規定によって，両数の格語尾である $\overline{1}, \overline{\mathrm{u}}, \mathrm{e} は$ は独立に発音されるべき語（pragrhya） とされ，連声の規則に従わなくてよいため， doșa とはならない. 同様に “himartau” の r も Pān 6.1.128の規定によって原形のままになっていると考えられる.

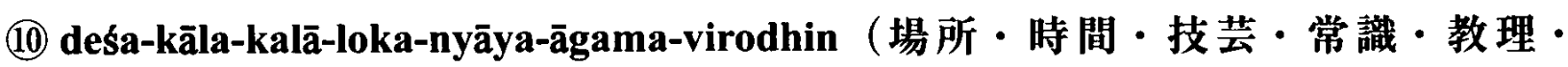
聖言に関する矛盾を含むもの)

詩作において，場所等の一般的な常識に適合しない表現を含む詩は，doṣa と なる (KA 3.162-164)，Dはこれら各々に対して詩例を与えている。

(a) deśaに関するものとは「梅檀（candana）の香りを運ぶ」という慣用が存在 するマラヤ山からの風を樟脳の樹木（karpūra-pāda）と結びつけたりする事等であ る (KĀ 1.65ab).

（b）kāla に関するものとは，昼咲きの蓮華（padminī）が夜に咲いたり，夜咲き の蓮（kumudvatī）が昼に開花したりする等 $(\mathrm{KA} 1.67 \mathrm{ab})$ ，適切な時間に矛盾する表 現である。

(c) kalāに関するものとは，インド古典劇等における rasa 理論において，rasa（情

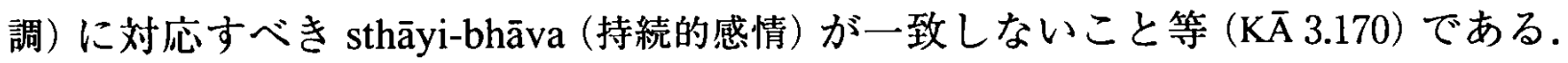

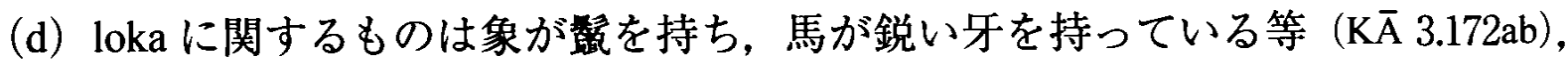
世間一般の認識に矛盾する表現である。

(e) nyāyaに関するものは，インドの諸思想の正論に関する矛盾を含む表現で ある。例えば $K \bar{A} 3.174-5$ の詩例に含まれる諸行の不滅や非存在からの創造等は 
仏教やサーンキヤ哲学の正論に明らかに矛盾している.

(f) āgamaに関するものは śruti とmṛtiに矛盾することである。例えば，前者 は聖火（agni）を設置せずに Vaiśvanārī 供犠祭を執行すること（KA 3.177）, 後者は 認可されずに（anupānīta）, 即ち入門式（upanayana, cf. Manusmrti 2.36ff.）を済ませず に師（guru）から諸ヴェーダを学ぶことが矛盾の例として示されている.

以上の通り，Dの説示したdoṣaは意味論, 韻律論, 文法論, 一般常識や慣例 に関するものに至るまで多岐に亘っている。いわば，それらは詩作にあたって詩 人たちが当然踏まえておくべき基礎的教養である。それら種々の doṣaに対して $\mathrm{D}$ が 60 もの詩節を割いて丁寧に詩例と解説を加えているという事実も, その点 を明確に証し立てていると言うべきであろう。

紙幅の都合上，本稿は註記を一切割愛し，KA における doṣa 論の概括に留めざ るを得なかった，同書に見られる豊富な詩例を含む詳論は別稿を期したい．また

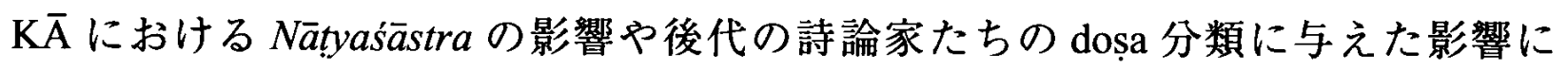
関しても今後の課題としたい.

〈略号・参考文献〉

$\mathrm{KA}:$ Kāvyādarśa of Daṇ̣in (ed. Böhtlingk); Pāṇ: Aștâahyāyī of Pāṇini (ed. Śrīśa Chandra Vasu); Dragomir Dimitrov [2011] : Śabdālaṃkāradoṣavibhāga (Wiesbaden); D.K.Gupta [1970]: A Critical Study of Dandin and His Works (Delhi); Yogeśvaradattaśarmā [1999]: Kāvyādarśa of Dandin, with Several Commentaries (Delhi).

〈キーワード〉 詩的欠陥（doșa）, Kāvyādarśa, 修辞学

(駒澤大学大学院) 